\title{
Goitre, lymphoma and the doughnut sign
}

\author{
Rajeev Sandal, Kundan Mishra, Aditya Jandial, Deepesh Lad
}

Internal Medicine, Postgraduate Institute of Medical Education and Research, Chandigarh, India

\section{Correspondence to}

Dr Kundan Mishra,

mishrak20@gmail.com

Accepted 22 August 2018

\section{DESCRIPTION}

A 65-year-old woman, with a known case of Hashimoto's thyroiditis on eltroxin for 15 years, presented with progressive diffuse swelling neck for 2 months. She also gave a history of difficulty in swallowing and breathing for 1 week. On examination, she had respiratory distress, low oxygen saturation $(85 \%$ on pulse oximeter) and cyanosed tongue. Systemic examination was unremarkable except for goitre (grade 2) and stridor. As the saturation was not improving with supplemental oxygen, she underwent an emergency tracheostomy. Subsequently,

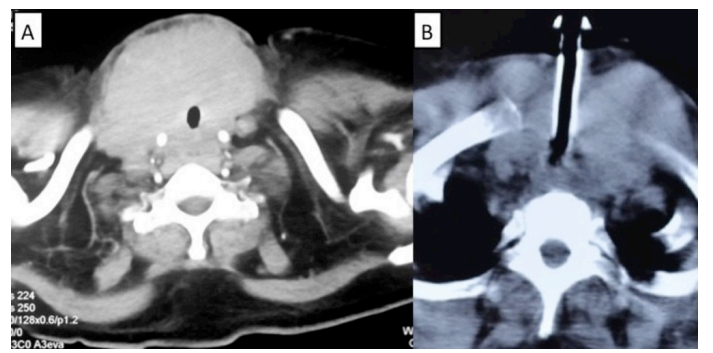

Figure 1 (A) CT neck image showing a homogenous mass encasing the trachea (doughnut sign) and invading the common carotid artery and the tracheo-oesophageal groove. (B) CT neck image showing tracheostomy tube.

\section{Learning points}

- Any follow-up case of Hashimoto's thyroiditis presenting with a rapidly enlarging neck mass, hoarseness of voice or difficulty in breathing or eating should be suspected of lymphoma transformation.

- The patient who develops doughnut sign is more symptomatic due to compressive symptoms.

- Prompt supportive care (tracheostomy in the index case) and definitive therapy (R-CHOP) is rewarding with a successful outcome. a contrast-enhanced CT scan of the neck showed large lobulated heterogeneously enhancing lesion in the region of thyroid gland encasing all major structure of neck including trachea (figure 1). Core biopsy and immunohistochemistry (CD45, CD20, CD10 and BCL6 positive) confirmed the diagnosis as diffuse large $\mathrm{B}$ cell lymphoma (DLBCL). The patient received R-CHOP chemotherapy (rituximab, cyclophosphamide, doxorubicin, vincristine and prednisolone). After 1 month, she was asymptomatic with $>50 \%$ decreased swelling, and the tracheostomy tube was removed.

Hashimoto's (autoimmune) thyroiditis is a known risk factor for thyroid lymphoma, making patients 60 times more prone to lymphoma than the general population. ${ }^{1}$ Primary thyroid lymphoma constitutes $1 \%-5 \%$ of thyroid malignancies. The majority (60\%-80\%) of thyroid lymphomas are DLBCL. ${ }^{2}$ On CT images, lymphoma can present with solid nodules, multiple nodules and diffuse swelling. In rare cases, it can present with the classical finding of 'doughnut sign' in which lymphoma completely encircle the trachea as in the index case. ${ }^{3}$

Contributors All authors managed the case at different stages. $\mathrm{RS}$ and $\mathrm{KM}$ wrote the manuscript, which was vetted by all.

Funding The authors have not declared a specific grant for this research from any funding agency in the public, commercial or not-for-profit sectors.

Competing interests None declared.

Patient consent Obtained.

Provenance and peer review Not commissioned; externally peer reviewed.

\section{REFERENCES}

1 Pedersen RK, Pedersen NT. Primary non-Hodgkin's lymphoma of the thyroid gland: a population based study. Histopathology 1996;28:25-

2 Czopnik P, Aporowicz M, Niepokój-Czopnik A, et al. Primary thyroid Iymphoma: a rare but challenging diagnosis. Pol Arch Intern Med 2017:127:361-4.

3 Muñoz de Nova JL, Rodríguez Sánchez A, Gómez Ramírez J, et al. [Doughnut sign in thyroid lymphoma]. Cir Esp 2013;91:e31.

Copyright 2018 BMJ Publishing Group. All rights reserved. For permission to reuse any of this content visit http://group.bmj.com/group/rights-licensing/permissions.

BMJ Case Report Fellows may re-use this article for personal use and teaching without any further permission.

Become a Fellow of BMJ Case Reports today and you can:

- Submit as many cases as you like

- Enjoy fast sympathetic peer review and rapid publication of accepted articles

- Access all the published articles

- Re-use any of the published material for personal use and teaching without further permission

For information on Institutional Fellowships contact consortiasales@bmjgroup.com

Visit casereports.bmj.com for more articles like this and to become a Fellow 